J. Perinat. Med. 15 (1987) 13

\section{Influence of nicotine chewing gum on fetal blood flow}

\author{
Annika Lindblad and Karel Maršál
}

Department of Obstetrics and Gynecology, General Hospital, Malmo, Sweden

\section{Introduction}

Smoking during pregnancy influences acutely both the maternal and the fetal circulation. It increases maternal heart rate and blood pressure [11] and reduces intervillous placental blood flow [5]. The fetus responses with an increased heart rate [11] and augmented aortic and umbilical blood flow [12].

It has been speculated that nicotine is the component in cigarette smoke responsible for the acute effects on fetal circulation [9, 11]. The purpose of the present study was to evaluate maternal and fetal hemodynamics after expo-

\section{Subjects and methods}

Twenty pregnant smokers who gave their informed consent participated in the study. Their mean daily consumption was 12 cigarettes (SD 5.3). The mean age of the women was 30.1 years (SD 3.8); 7 of the women were primiparas. All the pregnancies were uncomplicated with a singleton fetus in cephalic presentation. At the time of the study, the mean gestational age was 35.6 weeks (SD 2.2). Later at delivery, the mean gestational age was 39.8 weeks (SD 1.2) and the mean birth weight was $3424 \mathrm{~g}$ (SD 445). All newborns had Apgar scores more than 8 at both 1 and $5 \mathrm{~min}$. The mean umbilical arterial (SD 0.07), respectively. sure to nicotine only. and venous $\mathrm{pH}$ was 7.21 (SD 0.08) and 7.30

\section{Curriculum vitae}

ANNIKA LiNDBLAD, M.D., was graduated from the University of Lund in 1974. Since 1976, she has been a registrar at the Department of Obstetrics and Gynecology, General Hospital, Malmo, Sweden. In 1981, she specialized in Obstetrics and Gynecology. Her main field of interest is the fetal vascular response to different drugs.

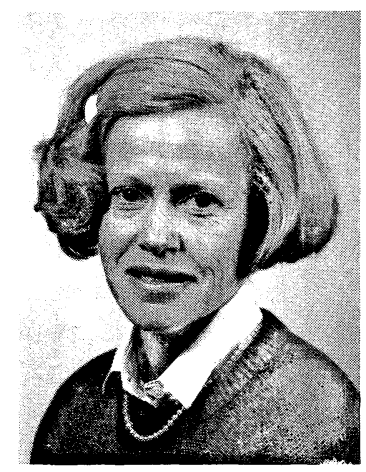

In a randomized double-blind fashion, the women chewed one day a chewing gum containing nicotine (nicotine gum) and another day a chewing gum without nicotine (placebo gum). The nicotine gum* consisted of a standard chewing gum base with the addition of $4 \mathrm{mg}$ nicotine bound to an ion exchanger. The women had been asked to abstain from smoking for at least twelve hours before the study. During the examination the women rested in a slightly left lateral position $\left(15^{\circ}\right)$. After three control measurements, the women chewed a gum for $30 \mathrm{~min}$. Recordings were made every 5 th $\mathrm{min}$ for $45 \mathrm{~min}$ after the commencement of chewing. The following parameters were recorded: maternal heart rate and blood pressure,

${ }^{*}$ Nicorette $^{\circledR}$, Leo, Helsingborg, Sweden 
fetal heart rate, fetal blood velocity and vessel diameter. Maternal heart rate was recorded by means of electrocardiogram and fetal heart rate was counted from the blood velocity traces. Blood velocity registrations from the thoracic part of the descending aorta were made in ten fetuses and from the intra-abdominal part of the umbilical vein in another ten fetuses. In 15 of the 20 fetuses recordings were also made from the umbilical artery in the umbilical cord.

Blood samples for determination of nicotine in plasma were taken in six women both before and 10, 25 and $45 \mathrm{~min}$ after the women had started to chew the gum. The nicotine concentrations were measured with a method comprising gas-liquid chromatography and mass-spectrometry (intra-assay coefficient of variation of $7 \%$ ).

The measurements of the blood flow were made by a method described by EIK-NES et al. [3] combining a real-time linear array scanner (ADR, Model 2130, Advanced Diagnostic Research Corporation, Tempe, Arizona; $3.5 \mathrm{MHz}$ ) and a pulsed Doppler instrument (ALFRED, Vingmed, A/S, Oslo, Norway; 2.0 MHz). The real-time scanner was calibrated to the velocity of sound $1540 \mathrm{~m} \cdot \mathrm{s}^{-1}$. The real-time scanner produced output ultrasound energy of $0.2 \mathrm{~mW}$. $\mathrm{cm}^{-2}$ (SATA) according to the manufacturer. The output ultrasound energy of the pulsed Doppler instrument was reduced and measured; the following ultrasound intensities were found at the surface of the transducer: SATA $27 \mathrm{~mW}$. $\mathrm{cm}^{-2}$, SPTA $103 \mathrm{~mW} \cdot \mathrm{cm}^{-2}$, SPTP and SPPA in the order of 1000 and $800 \mathrm{~mW} \cdot \mathrm{cm}^{-2}$, respectively (for definitions see ref. 13). A 100 $\mathrm{Hz}$ high-pass filtering of the Doppler signal was used to remove signals from slow moving tissues in the path of the beam. The Doppler transducer was attached to the real-time transducer at a fixed angle of $45^{\circ}$. The fetal vessel was visualized on the B-mode screen and the transducer moved until it was parallel to it. In this position the angle between the vessel and the Doppler beam was $45^{\circ}$ enabling correction of the recorded blood velocity for the angle. The calculations of blood velocity (V) at each registration were made on tracings of at least
$10 \mathrm{~s}$ duration under steady state conditions without fetal breathing and gross movements. Vessel cross-sectional area (A), assumed to be circular, was calculated from the mean value of ten vessel diameters measured in 10 frozen realtime images. The blood flow (Q) was calculated according to the formula $\mathrm{Q}=\mathrm{V} \cdot \mathrm{A} \cdot \cos$ $45^{\circ-1}$. The blood flow was related to the fetal weight estimated from the ultrasonically measured biparietal and abdominal diameters [2] and expressed in $\mathrm{ml} \cdot \min ^{-1} \cdot \mathrm{kg}^{-1}$. The waveform of the maximum velocity curves recorded from the fetal aorta and the umbilical artery was analyzed by a computer (ABC 806, Luxor, Motala, Sweden) and characterized by the following parameters: peak velocity (Vpeak), pulsatility index (PI) and rising slope (RS) [7]. The statistic evaluation was done by t-test for paired observation.

\section{Results}

After the nicotine gum, the maternal plasma nicotine concentration increased to a maximum value of $12.4 \mathrm{ng} / \mathrm{ml}$ (median) at $25 \mathrm{~min}$. After the placebo gum, the maternal nicotine concentration remained unchanged (figure 1).

On an average, $16 \%$ of the fetal registrations (14.9\% of the aortic recordings, $14.0 \%$ of the umbilical vein recordings and $17.5 \%$ of the umbilical artery recordings) had to be rejected because of fetal breathing or fetal gross movements.

The results concerning the maternal and fetal parameters are given in figures 2 and 3, respectively. There were no significant differences between the nicotine and placebo control values of the maternal and fetal parameters.

The maternal heart rate increased after the nicotine gum and the increase sustained for the study period ( $\mathrm{p}<0.001$ at 5 to $30 \mathrm{~min}, \mathrm{p}<$ 0.01 at 35 and $40 \mathrm{~min}$, and $\mathrm{p}<0.05$ at $45 \mathrm{~min}$ ). After the placebo gum, the maternal heart rate remained unchanged (except for measurements at 5 and $35 \mathrm{~min}, \mathrm{p}<0.01$ and $\mathrm{p}<0,001$, respectively). The maternal systolic blood pressure increased after the nicotine gum and the 


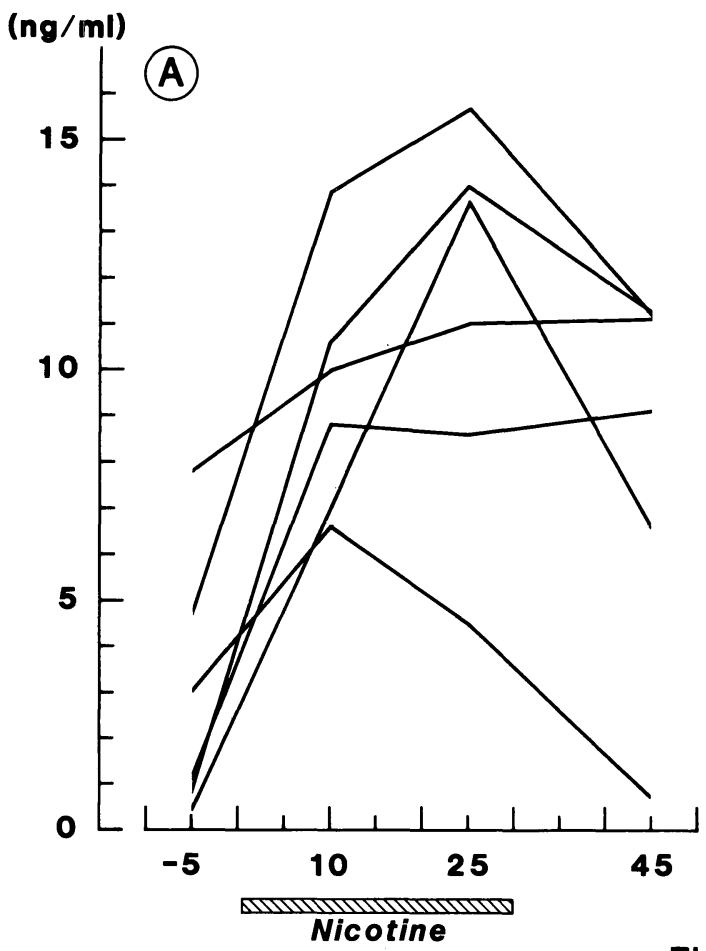

(ng/ml)

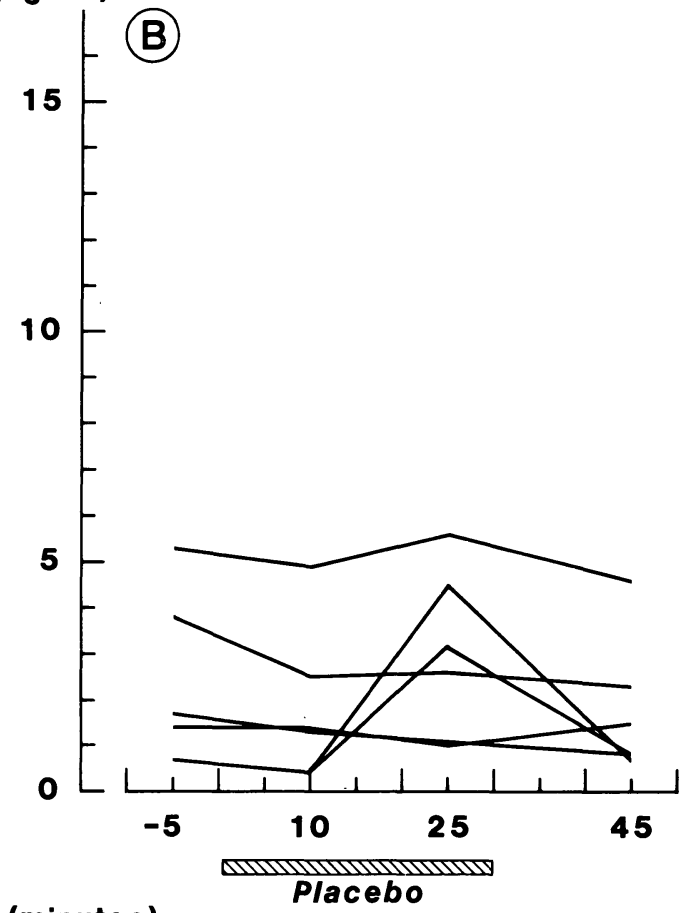

Time (minutes)

Figure 1. Maternal plasma concentrations of nicotine before and after a $4 \mathrm{mg}$ nicotine chewing gum (A) and before and after a placebo chewing gum $(B)(n=6)$.

increase was sustained for $30 \mathrm{~min}(\mathrm{p}<0.01$ at $5 \mathrm{~min}, \mathrm{p}<0.001$ at 10,15 and $20 \mathrm{~min}, \mathrm{p}<$ 0.05 at 25 and $30 \mathrm{~min})$. After the placebo gum, the systolic blood pressure remained unchanged (except for the measurements at $5 \mathrm{~min}, \mathrm{p}<$ 0.01 , and at 20 and $25 \mathrm{~min}, \mathrm{p}<0.05)$. The maternal diastolic blood pressure also increased after the nicotine gum and the increase was sustained for $35 \mathrm{~min}(\mathrm{p}<0.01$ at 5 and 30 $\min , \mathrm{p}<0.001$ at 10,15, 20, 25 and $35 \mathrm{~min}$ ). After the placebo gum, the diastolic blood pressure remained unchanged (except for the measurements at 10 and $15 \mathrm{~min}, \mathrm{p}<0.01$ ).

The fetal heart rate remained unchanged after both nicotine and placebo gums. The fetal aortic blood flow was unchanged after both the nicotine gum (except for the measurement at $20 \mathrm{~min}, \mathrm{p}<0.05$ ) and the placebo gum (except for the measurement at $30 \mathrm{~min}, \mathrm{p}<0.01$ ).
The waveform of the fetal aortic blood velocity showed no change in Vpeak, PI or RS after neither the nicotine nor the placebo gum. The umbilical venous blood flow remained the same both after the nicotine gum (except for the measurement at $15 \mathrm{~min}, \mathrm{p}<0.05$ ) and the placebo gum (except for the measurement at 25 min, $\mathrm{p}<0.01)$. In the 15 pregnant women for whom registrations were made from the umbilical artery after the placebo and the nicotine gum there was no change in any of the parameters of the maximum blood velocity waveform.

One fetus was noted to have a supraventricular arrhythmia 15 min after the woman had started to chew the nicotine gum and this arrhythmia was sustained through the study period. The next day the fetus had a regular heart rhythm before as well as after the placebo gum. 


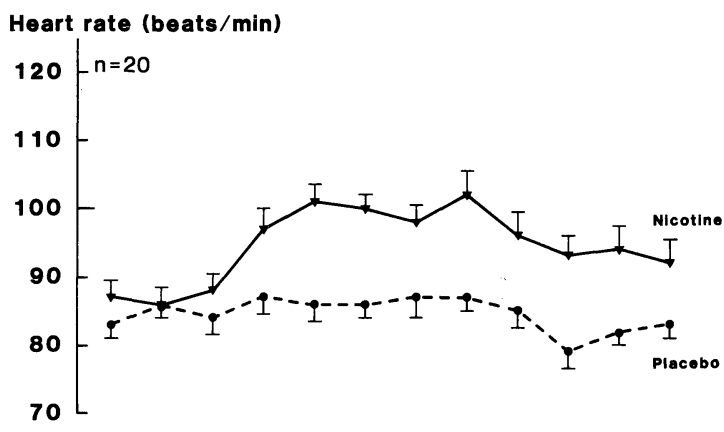

Blood pressure $(\mathrm{mm} \mathrm{Hg})$
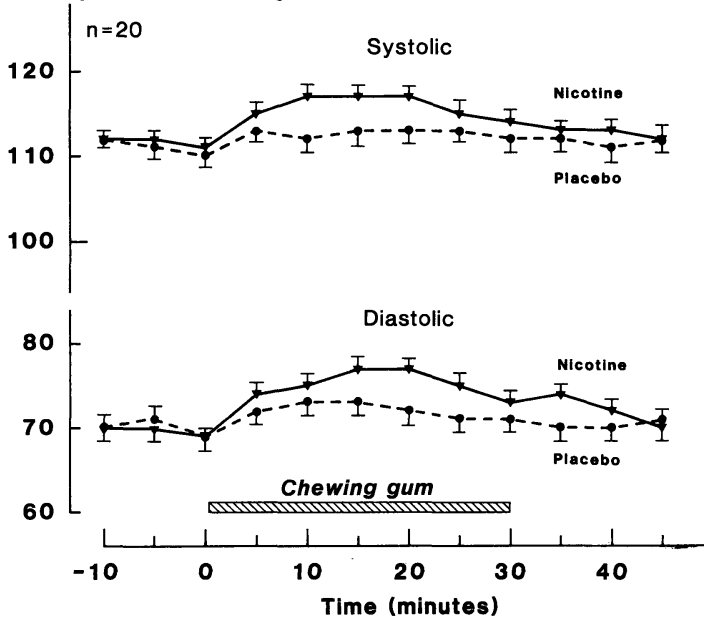

Figure 2. Influence of a $4 \mathrm{mg}$ nicotine chewing gum $(\boldsymbol{\nabla}-\boldsymbol{\nabla})$ and a placebo chewing gum (---) on maternal parameters. The horizontal bars denote the period of chewing $(0-30 \mathrm{~min})$. (Means $\pm \mathrm{SEM})$.

\section{Discussion}

We have thus found that a $4 \mathrm{mg}$ nicotine chewing gum increased maternal heart rate and blood pressure but did not affect fetal heart rate and blood flow. There was no change in the waveform of blood velocity, neither in the recordings from the fetal aorta nor the umbilical artery. This indicated that there was no change in the peripheral vascular resistance of the placenta.

PIJPERs et al. [10] and Jouppila et al. [4] measured fetal blood flow after smoking with the same technique as used in the present study. The former authors found a significant rise in
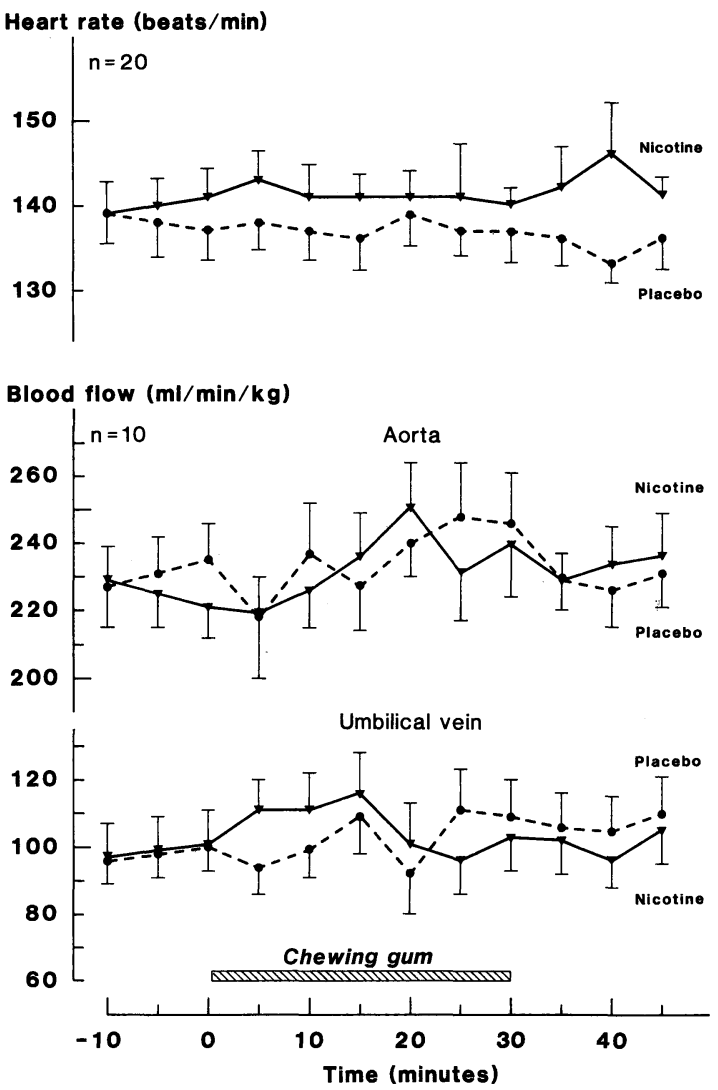

Figure 3. Influence of a $4 \mathrm{mg}$ nicotine chewing gum $(\boldsymbol{\nabla}-\boldsymbol{\nabla})$ and a placebo chewing gum (---) on fetal parameters. The horizontal bars denote the period of chewing $(0-30 \mathrm{~min})$. (Means $\pm \mathrm{SEM})$.

maternal heart rate, systolic blood pressure and fetal heart rate but no influence on fetal aortic blood velocity or vessel diameter when smoking one cigarette with a nicotine content of 1.0 mg. Jouppila et al. [4] found no immediate significant alterations, neither in the maternal parameters nor in the fetal aortic and umbilical blood flow after smoking one cigarette containing 0.6-1.2 mg nicotine. Maternal concentrations of nicotine in plasma were not determined in these two studies. However, smoking one cigarette yielding $0.8-1.1 \mathrm{mg}$ nicotine gives plasma nicotine levels comparable to the levels obtained after a $4 \mathrm{mg}$ nicotine gum [8]. Accordingly, one can presume that the pregnant women in these two studies had plasma nicotine 
levels comparable to those we found after the $4 \mathrm{mg}$ nicotine gum.

SindBerg ERIKSEN and MarŠÁl [12] found a significant rise in maternal heart rate, systolic and diastolic blood pressure, fetal heart rate, fetal aortic and umbilical venous blood flow following one cigarette yielding $1.6 \mathrm{mg}$ nicotine. Maternal plasma nicotine concentrations increased from a median value of $<2 \mathrm{ng} \cdot \mathrm{ml}^{-1}$ prior to smoking to a median of $26 \mathrm{ng} \cdot \mathrm{ml}^{-1}$ $10 \mathrm{~min}$ after the onset of smoking. Forty-five min after the onset of smoking the nicotine level had decreased to $8 \mathrm{ng} \cdot \mathrm{ml}^{-1}$. Thus the high-dose cigarette gives a plasma nicotine level that is twice as high as obtained after chewing the $4 \mathrm{mg}$ nicotine gum.

\section{Summary}

Several studies have shown that smoking is not beneficial to the fetus. Among the acute effects, influence on fetal circulation has been reported. Nicotine is considered to be one of the active agents in cigarette smoke. To test the nicotine effects on the human fetus, maternal and fetal cardiovascular dynamics were studied in 20 pregnant women when chewing a chewing gum containing $4 \mathrm{mg}$ of nicotine and a chewing gum without nicotine given in a randomized double blind order. The fetal blood flow was measured with a method combining realtime ultrasonography and pulsed Doppler technique. Registrations were made in ten fetuses from the thoracic part of the descending aorta and in ten fetuses from the intra-abdominal part of the umbilical vein. In 15 of the fetuses registrations were also made from the umbilical artery. Concentrations of nicotine in plasma were analyzed in six women.

The maternal plasma nicotine concentrations increased after the nicotine gum to a maximum value of $12.4 \mathrm{ng}$. $\mathrm{ml}^{-1}$ (median) at $25 \mathrm{~min}$ (figure 1). The $4 \mathrm{mg}$ nicotine

Keywords: Fetal circulation, nicotine, ultrasound.

\section{Zusammenfassung}

Einfluß von nikotinhaltigem Kaugummi auf den fetalen Blutstrom

Mehrere Untersuchungen haben gezeigt, daß das Rauchen für den Fetus eine ungünstige Wirkung hat. Ein direkter Einfluß auf die fetale Zirkulation wurde als einer der akuten Effekte beobachtet, und das Nikotin im Zigarettenrauch wurde als die aktive Substanz angegeben. Der Einfluß des Nikotins auf die menschliche fetale kardiovaskulare Dynamik wurde in einer rando-
The fact, that a $4 \mathrm{mg}$ nicotine gum, in contrast to a cigarette, does not affect the fetal circulation, might depend on some other active component in the cigarette smoke. In addition to nicotine, smoking involves inhalation of carbon monoxide (CO) with a resultant increase in maternal and fetal $\mathrm{HbCO}$ concentration [1]. Absence of $\mathrm{CO}$ in our study hardly explains the different response compared with that found by SindBerg ERIKSEN and MARŠÁL, as the transfer of $\mathrm{CO}$ from mother to fetus is low during the first hour, as has been demonstrated in pregnant ewes [6]. It seems more likely that the different fetal hemovascular responses are dependent on the dose of nicotine used.

gum increased significantly maternal heart rate, systolic and diastolic blood pressure (figure 2). There was no influence on fetal heart rate or fetal blood flow, neither in the thoracic part of the descending aorta, nor in the intra-abdominal part of the umbilical vein (figure 3 ). There were no changes in the waveforms of the maximum blood velocity curves, neither of the aorta nor the umbilical artery. This indicates that there was no increased resistance in the placenta, neither after the nicotine gum nor the placebo gum.

Chewing the $4 \mathrm{mg}$ nicotine gum does not seem to affect fetal circulation acutely. This is in contrast to smoking a cigarette yielding $1.6 \mathrm{mg}$ nicotine (high-dose cigarette). This could hardly be explained by $\mathrm{CO}$ in the cigarette smoke as $\mathrm{CO}$ only slowly passes the placenta. The maternal nicotine plasma concentrations after smoking a high-dose cigarette are doubled compared with the levels after a low-dose cigarette $(0.8-1.1 \mathrm{mg}$ nicotine) or a $4 \mathrm{mg}$ nicotine gum. Thus it is likely that the nicotine influence on the fetal circulation is dose dependent. misierten Doppelblindstudie untersucht. 20 graviden Frauen wurde Kaugummi mit $4 \mathrm{mg}$ Nikotin oder Kaugummi ohne Nikotin verabreicht und der fetale Blutkreislauf mit einer kombinierten Real-time Ultraschallund gepulsten Doppler-Technik gemessen. Bei 10 Feten wurde die Registrierung in dem unteren thorakalen Teil der Aorta descendens und bei 10 Feten in dem intraabdominalen Teil der Nabelvene durchgeführt. Bei 15 der Feten wurde die Registrierung auch in der Nabelarterie 
vorgenommen. Die Nikotinkonzentration im Plasma wurde bei 6 Frauen analysiert.

Nach nikotinhaltigem Kaugummi ist die mütterliche Plasmanikotinkonzentration auf einen maximalen Wert $12,4 \mathrm{ng} \cdot \mathrm{ml}^{-1}$ nach $25 \mathrm{Min}$. gestiegen (Abb. 1). Der Kaugummi mit $4 \mathrm{mg}$ Nikotin erhöhte signifikant die mütterliche Herzfrequenz und den systolischen und diastolischen Blutdruck. Ein Einfluß auf die fetale Herzfrequenz oder auf den fetalen Blutstrom in der Aorta oder in der Nabelvene konnte nicht nachgewiesen werden (Abb. 2). Veränderungen der Wellenform der maximalen Blutstromgeschwindigkeit in der fetalen Aorta oder in der Nabelarterie sind nicht vorgekommen. Dies deutet darauf hin, daß der nikotinhaltige Kaugummi und Place-
bo-Kaugummi den Widerstand in der Plazenta nicht erhöht haben.

Im Gegensatz zum Rauchen einer hochdosierten Zigarette mit 1,6 mg Nikotin scheint der Kaugummi mit $4 \mathrm{mg}$ Nikotin den fetalen Blutkreislauf nicht $\mathrm{zu}$ beeinflussen. Dies kann man wahrscheinlich nicht durch den CO-Inhalt im Zigarettenrauch erklären, weil $\mathrm{CO}$ nur langsam die Plazenta passiert. Die mütterliche Plasmanikotinkonzentration nach dem Rauchen einer hochdosierten Zigarette ist doppelt so hoch wie nach einer niedrigdosierten Zigarette (0,8-1,1 mg Nikotin) oder nach $4 \mathrm{mg}$ Nikotin-Kaugummi. Es ist wahrscheinlich, daß der Einfluß des Nikotins auf den fetalen Blutkreislauf dosisabhängig ist.

Schlüsselwörter: Fetaler Blutkreislauf, Nikotin, Ultraschall.

\section{Résumé}

\section{Influence des chewing-gums à la nicotine sur la circulation fætale}

Plusieurs études ont montré que l'action de fumer n'est pas salutaire pour le fœtus. Parmi les effets aigus, on a rapporté l'influence sur la circulation fœtale. La nicotine est considérée comme un des agents actifs dans la fumée de cigarette. Pour tester les effects de la nicotine sur le fœtus humain, on a étudié la dynamique cardiovasculaire maternelle et fœtale chez 20 femmes enceintes mâchant un chewing-gum contenant $4 \mathrm{mg}$ de nicotine et un chewing-gum sans nicotine, donnés en double aveugle avec randomisation. On a mesuré le flux sanguin fœtal à l'aide d'une méthode combinant une échographie en temps réel et un Doppler pulsé. Chez dix fœtus, on a fait les enregistrements dans la portion thoracique descendante de l'aorte et chez dix fœtus dans la partie intraabdominale de la veine ombilicale. Chez 15 de ces fœtus, on a fait également les enregistrements de l'artère ombilicale. Chez six femmes, on a analysé la nicotinémie. Les concentrations en nicotine du plasma maternal, après avoir mâché un chewing-gum avec nicotine, augmentent jusqu'à une valeur maximale de $12.4 \mathrm{ng} \cdot \mathrm{ml}^{-1}$ (médiane) après $25 \mathrm{~min}$. (figure 1). Le chewing-gum contenant $4 \mathrm{mg}$ de nicotine augmente significativement la fréquence des pulsations cardiaques maternelles ainsi que la tension artérielle systolique et diastolique (figure 2). Il n'y a pas d'influence sur le rythme cardiaque fœtal ni sur le flux sanguin fotal, tant dans la partie thoracique descendante de l'aorte, que dans la partie intraabdominale de la veine ombilicale (figure 3 ). Il n'y a pas de changements dans la forme des ondes des courbes de vitesse maximum du sang, ni dans l'aorte, ni dans l'artère ombilicale. Ceci indique qu'il n'y a pas d'augmentation des résistances placentaires, ni après avoir mâché un chewing-gum avec nicotine, ni après un chewing-gum sans nicotine.

Le chewing-gum à $4 \mathrm{mg}$ de nicotine ne semble pas affecter intensément la circulation fotale. Ceci est en contraste avec le fait de fumer une cigarette exhalant $1.6 \mathrm{mg}$ de nicotine (cigarette à haute teneur). Ceci pourrait tout au plus s'expliquer par le $\mathrm{CO}$ contenu dans la fumée de la cigarette, comme le $\mathrm{CO}$ passe seulement lentement le placenta. La concentration en nicotine du plasma maternel après avoir fumé une cigarette à haute teneur est doublée, en comparaison avec les concentrations obtenues après une cigarette à faible teneur $(0.8-1.1 \mathrm{mg}$ de nicotine) ou un chewing-gum à $4 \mathrm{mg}$ de nicotine. Par conséquent, il est vraisemblable que l'influence de la nicotine sur la circulation fœtale est dépendante de la dose.

Mots-clés: Circulation fœtale in utéro, mesure par ultrasons de la circulation fœtale, nicotine.

Acknowledgements: This study was supported by the Swedish Medical Research Council (Grant No. 5980), the Medical Faculty, University of Lund, and the Swedish Tobacco Company (Grant No. 8313).

\section{References}

[1] Cole PV, LH Hawkins, D RoBert: Smoking during pregnancy and its effects on the fetus. J Obstet Gynaecol Br Cwlth 79 (1972) 782

[2] EiK-Nes SH, P Gröttum, PH Persson, K MARŠÁL: Prediction of fetal growth deviation by ultrasonic biometry. Acta Obstet Gynecol Scand 61 (1982) 53
[3] EiK-Nes SH, K MARŠÁL, K KRISTOFFERSEN: Methodology and basic problems related to blood flow studies in the human fetus. Ultrasound Med Biol 10 (1984) 329

[4] Jouppila P, P KIRKInEN, SH EIK-Nes: Acute effect of maternal smoking on the human fetal blood flow. Br J Obstet Gynaecol 90 (1983) 7 
[5] LehtovirTa P, M Forss: The acute effect of smoking on intervillous blood flow of the placenta. $\mathrm{Br}$ J Obstet Gynaecol 85 (1978) 729

16] LoNGo LD: The biological effects of carbon monoxide on the pregnant woman, fetus, and newborn infant. Am J Obstet Gynecol 129 (1977) 69

[7] MCCALLum WD: Fetal cardiac anatomy and vascular dynamics. Clin Obstet Gynecol 24 (1981) 837

[8] MC NABb ME, RV EberT, K Mc Cusker: Plasma nicotine levels produced by chewing nicotine gum. JAMA 248 (1982) 865

[9] Manning FA, C Feyerabend: Cigarette smoking and fetal breathing movements. Br J Obstet Gynaecol 83 (1976) 262

[10] Pijpers L, JW Wladimiroff, JS McGhie, N Bom: Acute effect of maternal smoking on the maternal and fetal cardiovascular system. Early Hum Dev 10 (1984) 95
[11] Quigley MD, KL Sheehan, MM Wilkes, SSC YEN: Effects of maternal smoking on circulating catecholamine levels and fetal heart rates. Am J Obstet Gynecol 133 (1979) 685

[12] SindBerg ERIKSEN P, K MARŠÁL: Acute effects of maternal smoking on fetal blood flow. Acta Obstet Gynecol Scand 63 (1984) 391

[13] Wно (World Health Organization): Ultrasound, Environmental Health Criteria 22, pp 196. World Health, Geneva 1982

Received November 18, 1985. Accepted July 5, 1986.

Annika Lindblad, MD

Department of Obstetrics and Gynecology General Hospital

S-21401 Malmo, Sweden 